\title{
Exploring the coupling relationship between hydrocarbon generation of continental shale and nanopore structure evolution-A case study of Shahejie formation in Bohai Bay Basin
}

\author{
Youwei Zheng ${ }^{1} \cdot$ Deliang $\mathrm{Fu}^{2} \cdot$ Jianqiang Qin ${ }^{2} \cdot$ Xianrong Liu $^{2} \cdot$ Bing Tian $^{1} \cdot$ Lina Sun $^{3}$
}

Received: 23 May 2021 / Accepted: 23 September 2021 / Published online: 9 October 2021

(c) The Author(s) 2021

\begin{abstract}
The nano-scale pore structure of shale is closely related to the self-generated and self-accumulated shale oil and gas. The Bohai Bay Basin is a crucial oil-bearing basin in eastern China, and the Paleogene Shahejie Formation is the most important source rock section in this area. In order to study the internal relationship between hydrocarbon generation evolution and pore structure characteristics of source rocks, we conducted hydrocarbon generation simulation tests with a closed gold tube system, and heated up original rocks from Shahejie Formation in Laizhou Bay Sag, southern Bohai Bay Basin, from $290{ }^{\circ} \mathrm{C}$ to $440^{\circ} \mathrm{C}$ at different heating rates. Besides, we carried out low-temperature $\mathrm{N}_{2}$ adsorption experiments on sample residues, and measured their pore structure characteristic parameters. The results show that with the increase of simulated temperature, the specific surface area and pore volume of nano-pores below $10 \mathrm{~nm}$ (which are mainly organic pores) decrease first and then increase, while those of nano-pores above $10 \mathrm{~nm}$ increase all the way. The evolution trend of total specific surface area and pore volume is mainly controlled by pores below $10 \mathrm{~nm}$ which are mainly organic pores, especially micropores below $2 \mathrm{~nm}$. There are two main factors affecting the development of inorganic pores: (1) Dissolution of organic acids produced by pyrolysis of organic matter in hydrocarbon-generation evolution; (2) Deformation of crystal structure of mineral components under the combined action of temperature and pressure. The experimental results at different heating rates demonstrate that rapid settlement under geological conditions is not conducive to the development of nano-pores, especially micro-pores composed of organic pores.
\end{abstract}

Keywords Continental shale $\cdot$ Hydrocarbon generation $\cdot$ Nanopore structure $\cdot$ Shahejie formation $\cdot$ Bohai Bay Basin

\section{Introduction}

Unconventional oil and gas, represented by shale oil and gas, affect the global energy structure profoundly. However, due to factors such as tight shale reservoir and poor permeability, prediction of sweet spots of shale oil and gas resources has become a major problem. Its reservoir space is dominated by nano-scale pores in shale, and the reservoir modes mainly

Deliang Fu

fud13513@foxmail.com

1 Inner Mongolia University of Science and Technology, Baotou 014010, China

2 Key Laboratory of Coal Resources Exploration and Comprehensive Utilization, Ministry of Natural Resourcess, Xi' an 710021, China

3 Yangtze University, Wuhan 434023, China include adsorption state, free state and dissolved state(Curtis 2002; Montgomery et al. 2005; Jarvie et al. 2007; Ross and Bustin 2009; Li et al. 2014; Zhao et al. 2020). The pore structure of shale is the key factor to determine whether the fluid exists in adsorbed or free state. The mobility study of shale oil in Zhanhua Sag pointed out that movable shale oil mainly exists in pores with pore size above $50 \mathrm{~nm}$ (Jiang et al. 2020). For pores below $50 \mathrm{~nm}$, they have a large specific surface area and poor connectivity, making shale oil absorbed on the pore surface and thus difficult to flow. In fact, with the change of fluid composition caused by the increase of thermal evolution, the critical pore size will also change. A large number of studies show that the mobility of shale oil is positively correlated with the total pore volume, total effective pore volume and average pore diameter of reservoir. (Huang et al. 2018; Li et al. 2019; Ning et al. 2020).

Shale pores are divided into organic pores, mineral matrix pores and micro-fractures, and the first two types are 
directly affected by the evolution of hydrocarbon generation (Loucks et al. 2009). During this process, with the hydrocarbon generation and expulsion, the structure of organic matter changes and then forms organic pores. These pores are affected by the type and maturity of organic matter (Sun et al. 2015; Topór et al. 2017). On the one hand, the development of mineral matrix pores is influenced by diagenetic evolution. On the other hand, it is also reformed by hydrocarbon generation from organic matter (Jiang et al. 2017; Wang et al. 2017; Wu et al. 2017). Through the hydrous simulation experiment, it is found that the pore evolution of shale changes little with the increase of thermal maturity, and the rapid formation of secondary pores is at the peak of oil generation (Sun et al. 2015). At this stage, the specific surface area and pore volume of nano-pores increase with the degree of thermal evolution. Wu et al. (2015)pointed out that the nanopore of continental shale decreased rapidly in the early stage of hydrocarbon generation due to compaction. Then, it increased dramatically after entering the stage of rapid hydrocarbon generation due to the generation of a large amount of oil and gas and the compaction of clay minerals.

The third member of Shahejie Formation in Bohai Bay Basin has great resource potential of shale oil and gas. But there is little research on the relationship between pore structure characteristics and hydrocarbon generation evolution in this area. This paper makes a detailed study on the hydrocarbon generation evolution characteristics and pore structure development process of the source rocks through the simulation experiment of gold tube hydrocarbon generation in a closed system and low temperature $\mathrm{N}_{2}$ physical adsorption experiment. It aims to explain the internal relationship between nano-pore structure and hydrocarbon generation evolution, and provide technical reference for exploration and development of shale oil and gas resources in this area.

\section{Samples and experiments}

\section{Samples}

The samples in this study are collected from the carbonaceous mudstone of the third member of Shahejie Formation in Laizhou Bay Sag, Bohai Bay Basin. The basic geochemical characteristics of the samples are shown in Table 1.

\section{Experiments}

The samples are ground to granules under 100 mesh by a crusher. After the dissolved organic matter is removed by Soxhlet extraction, the samples are put into a gold tube $(40 \mathrm{~mm} \times 2.5 \mathrm{~mm} \times 0.25 \mathrm{~mm})$ and sealed by argon arc 
welding in argon atmosphere. The weight of the samples in each gold tube ranges from $450 \mathrm{mg}-800 \mathrm{mg}$. The sealed sample is put into a stainless steel autoclave and heated in a high-temperature pyrolysis furnace. We use a pressure parallel device to keep the experiment pressure at $50 \mathrm{Mpa}$, with an error of $\pm 2 \mathrm{MPa}$. Here is the temperature rise process: First, the temperature is increased from room temperature to $250{ }^{\circ} \mathrm{C}$ in $10 \mathrm{~h}$. Then we raise it to the target temperature at two heating rates, $2{ }^{\circ} \mathrm{C} / \mathrm{h}$ and $20^{\circ} \mathrm{C} / \mathrm{h}$, respectively. The temperature error is $\pm 1^{\circ} \mathrm{C}$. Samples are taken according to the set temperature points, and each heating rate has 7 temperature points. More details about simulation experiments can be found in previous studies (Fu et al. 2020; Tian et al. 2008; Wang et al. 2013).

\section{Quantification of hydrocarbon generation rate}

After the simulation experiment, we analyze the gas composition on HP7890A gas chromatograph equipped with Walson ECE module. Specifically, we put gold tubes into the vacuum pumping system and puncture them with a steel needle, as external standard method after gas chromatography. Chromatographic column model is HP-Al/S $(25 \mathrm{~m} \times 0.32 \mathrm{~mm} \times 8.0 \mu \mathrm{m})$, and helium is used as the carrier gas. The heating procedure is as follows: The initial temperature is kept at $60^{\circ} \mathrm{C}$ for $3 \mathrm{~min}$. Then, it is raised to $190{ }^{\circ} \mathrm{C}$ at a rate of $25^{\circ} \mathrm{C} / \mathrm{min}$, the temperature remains unchanged for $3 \mathrm{~min}$.

$\mathrm{C}_{7+}$ component analysis is divided into $\mathrm{C}_{7-14}$ and $\mathrm{C}_{14+}$. For $\mathrm{C}_{7-14}$, after the gas component analysis, the remaining gas in the system is frozen in a $4 \mathrm{~mL}$ sample bottle with a liquid nitrogen cold trap, and n-hexane solvent is added. Then we cut the gold tube and soak it in the solvent to fully dissolve $\mathrm{C}_{7-14}$, which is quantitatively analyzed in Agilent $7890 \mathrm{~A}$ gas chromatograph with deuterated $\mathrm{C}_{24}$ alkane as internal standard. The chromatographic column model is DM-5 $(30 \mathrm{~m} \times 0.32 \mathrm{~mm} \times 0.25 \mu \mathrm{m})$, and helium is used as the carrier gas. The heating procedure is as follows: The initial temperature stays at $40^{\circ} \mathrm{C}$ for $5 \mathrm{~min}$. Then, it is raised to $290{ }^{\circ} \mathrm{C}$ at a rate of $4{ }^{\circ} \mathrm{C} / \mathrm{min}$ and the temperature remains unchanged for $15 \mathrm{~min}$. When the analysis is completed, let the sample stand. After n-hexane volatilizes completely, add dichloromethane and make the sample stand for $72 \mathrm{~h}$. Then, we conduct 30 min' ultrasonic treatment. After that, the residue of the samples are filtered to obtain the constant weight of $\mathrm{C}_{14+}$ components and then the filtered samples are weighed. Finally, the above two components are added to obtain total $\mathrm{C}_{7+}$.

\section{Pore structure analysis}

The pore structure of the solid residue obtained by filtration is analyzed by $\mathrm{N}_{2}$ adsorption experiment at low temperature. During the experiment, we adopt the ASAP2460 automatic physical adsorption instrument produced by Micromeritics. Without further treatment, the solid residue is directly put into a sample test tube and degassed in vacuum at $110{ }^{\circ} \mathrm{C}$ for more than $24 \mathrm{~h}$. Then, nitrogen is introduced in stages at $-191.2^{\circ} \mathrm{C}$ for adsorption-desorption experiment. According to the nitrogen adsorption capacity of the samples under different pressure conditions, we calculate the specific surface area of the samples by multi-point BET model linear regression, and obtain the pore volume and the relationship between specific surface area and pore size distribution.
Table 2 Determination of hydrocarbon generation and pore structure parameters of samples

\begin{tabular}{|c|c|c|c|c|c|c|c|c|}
\hline $\begin{array}{l}\text { Sample size } \\
\mathrm{mg}\end{array}$ & $\begin{array}{l}\mathrm{T} \\
{ }^{\circ} \mathrm{C}\end{array}$ & $\begin{array}{l}\text { Heating rate } \\
{ }^{\circ} \mathrm{C} / \mathrm{h}\end{array}$ & $\begin{array}{l}\text { Easy\%Ro } \\
\%\end{array}$ & $\begin{array}{l}\text { Total gas } \\
\mathrm{mL} / \mathrm{g}\end{array}$ & $\begin{array}{l}\text { Total oil } \\
\mathrm{mg} / \mathrm{g}\end{array}$ & $\begin{array}{l}\text { TOC } \\
\%\end{array}$ & $\begin{array}{l}\mathrm{S}_{\mathrm{BET}} \\
\mathrm{m}^{2} / \mathrm{g}\end{array}$ & $\begin{array}{l}\mathrm{V}_{\mathrm{BJH}} \\
\mathrm{cm}^{3} / \mathrm{g}\end{array}$ \\
\hline 797.74 & 330.0 & 20 & 0.55 & 0.07 & 2.59 & 5.51 & 15.5348 & 0.027715 \\
\hline 813.28 & 350.1 & 20 & 0.64 & 0.20 & 5.11 & 5.11 & 8.3470 & 0.022046 \\
\hline 749.26 & 369.8 & 20 & 0.72 & 0.39 & 8.13 & 4.81 & 6.9051 & 0.021537 \\
\hline 796.86 & 390.3 & 20 & 0.83 & 0.56 & 9.74 & 4.63 & 3.8659 & 0.020414 \\
\hline 800.61 & 400.5 & 20 & 0.89 & 0.75 & 10.56 & 4.43 & 7.2264 & 0.030354 \\
\hline 699.49 & 419.9 & 20 & 1.07 & 1.61 & 10.74 & 4.22 & 14.7066 & 0.050414 \\
\hline 649.91 & 430.8 & 20 & 1.17 & 2.15 & 8.83 & 4.01 & 16.3152 & 0.050688 \\
\hline 801.56 & 300.0 & 2 & 0.56 & 0.10 & 3.33 & 5.56 & 19.1350 & 0.031156 \\
\hline 798.36 & 319.9 & 2 & 0.65 & 0.22 & 5.53 & 5.17 & 14.0484 & 0.027592 \\
\hline 799.06 & 340.0 & 2 & 0.75 & 0.42 & 8.92 & 4.82 & 10.8136 & 0.024713 \\
\hline 799.93 & 349.9 & 2 & 0.80 & 0.53 & 10.58 & 4.54 & 6.8240 & 0.022013 \\
\hline 800.01 & 360.0 & 2 & 0.86 & 0.69 & 11.64 & 4.37 & 11.0861 & 0.031340 \\
\hline 700.54 & 380.3 & 2 & 1.04 & 1.45 & 12.76 & 4.27 & 16.7747 & 0.043674 \\
\hline 495.83 & 400.1 & 2 & 1.26 & 2.64 & 7.30 & 4.16 & 22.3982 & 0.052785 \\
\hline
\end{tabular}




\section{Experiment results}

Table 2 and Fig. 1 present the hydrocarbon production rate, pore specific surface area, and pore volume test results of the samples at different heating rates.

The gas generation rate of experiment samples continues to rise with the increase of simulated temperature. The corresponding temperature of rapid gas generation is 400.5 ${ }^{\circ} \mathrm{C}$ at $20{ }^{\circ} \mathrm{C} / \mathrm{h}$ and $360.0{ }^{\circ} \mathrm{C}$ at $2{ }^{\circ} \mathrm{C} / \mathrm{h}$, which are similar to the maximum generation rate of liquid hydrocarbon. The maximum generation rate of gaseous hydrocarbon is $2.15 \mathrm{~mL} / \mathrm{g}$ at $430.8^{\circ} \mathrm{C}$ at $20^{\circ} \mathrm{C} / \mathrm{h}$. The maximum generation

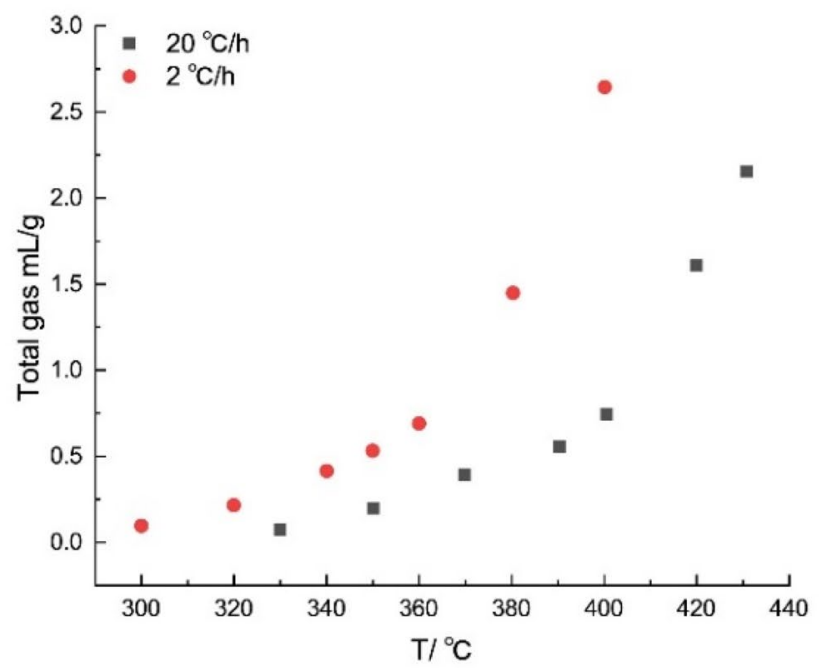

a

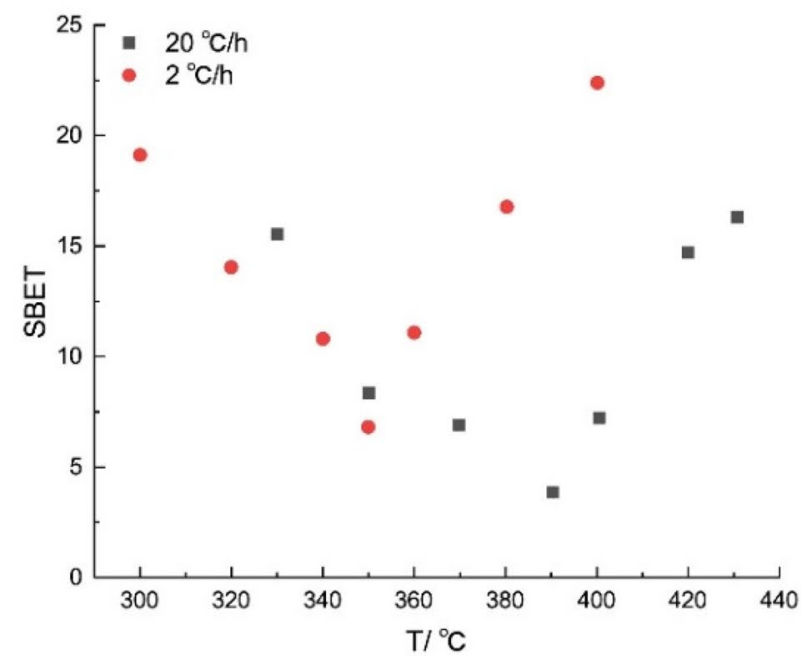

C rates of liquid hydrocarbon at two heating rates are 419.9 ${ }^{\circ} \mathrm{C}$ at $20^{\circ} \mathrm{C} / \mathrm{h}$ and $380.3{ }^{\circ} \mathrm{C}$ at $2{ }^{\circ} \mathrm{Ch}$, respectively. With the increase of the simulated temperature, the specific surface area and pore volume of the samples decrease first and then increase. Under the heating rate of $20^{\circ} \mathrm{C} / \mathrm{h}$, the BET specific surface area and $\mathrm{BJH}$ pore volume reach the lowest at $390.3{ }^{\circ} \mathrm{C}$, while under $2{ }^{\circ} \mathrm{C} / \mathrm{h}$, they reach the lowest at $349.9^{\circ} \mathrm{C}$. In terms of the pore structure parameters under the two heating rates, below $349.9{ }^{\circ} \mathrm{C}$, with the increase of temperature, the evolution trend of pore specific surface area and pore volume is similar. When the temperature is higher than $349.9{ }^{\circ} \mathrm{C}$, the pore specific surface area and

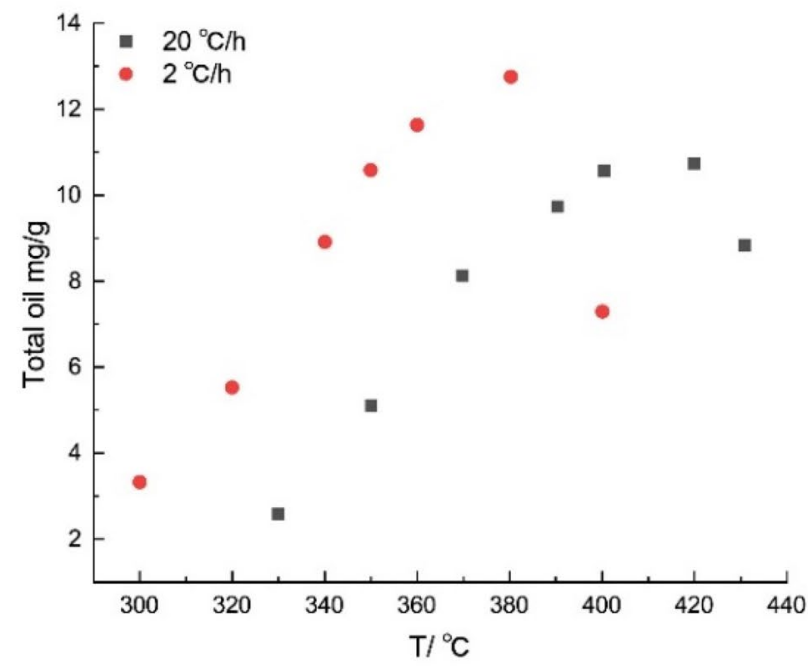

$\mathrm{b}$

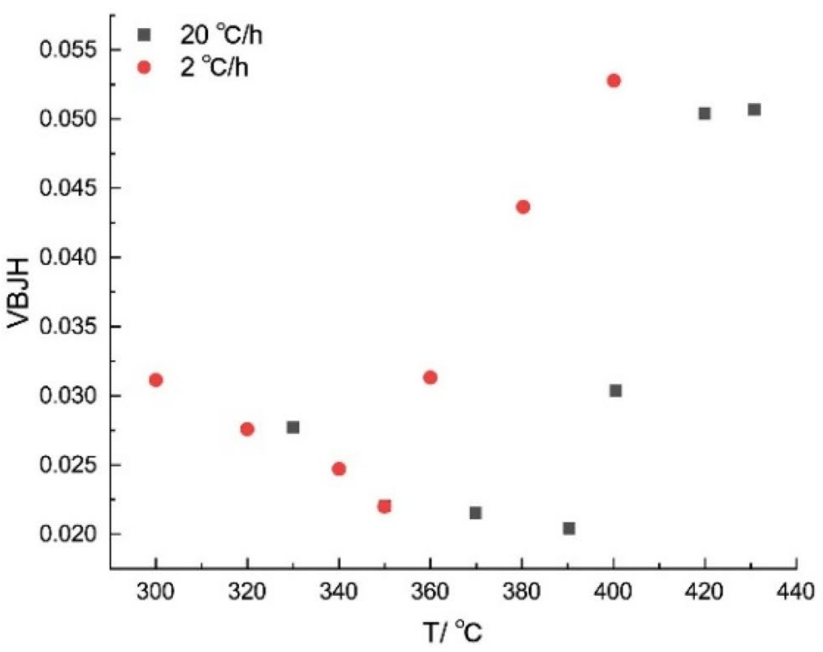

d

Fig. 1 Characteristics of hydrocarbon yield and pore structure change of samples from simulated experiments $\mathbf{a}$ : total gas; $\mathbf{b}$ : total oil; $\mathbf{c}: \mathrm{S}_{\mathrm{BET}} ; \mathbf{d}$ : $\mathrm{V}_{\mathrm{BJH}}$ ) 
pore volume under slow heating conditions are obviously higher than those under rapid heating conditions at the same temperature (Fig. 1).

\section{Discussion}

\section{Decrease stage of pore specific surface area and pore volume}

During the decrease of pore specific surface area and pore volume (Figs. 2, 3), on the curve at the heating rate of $20{ }^{\circ} \mathrm{C} / \mathrm{h}$, it can be seen that with the increase of simulation temperature, the pore volume and specific surface area larger than $10 \mathrm{~nm}$ increase as a whole, while pores smaller than $10 \mathrm{~nm}$ decrease, especially those with a diameter below $2 \mathrm{~nm}$. On the other hand, when the heating rate is $2{ }^{\circ} \mathrm{C} / \mathrm{h}$, the changes of pores with its diameter above $10 \mathrm{~nm}$ are less obvious than those at $20^{\circ} \mathrm{C} / \mathrm{h}$. But the general trend is similar. It is concluded that the decrease of pores below $10 \mathrm{~nm}$, especially below $2 \mathrm{~nm}$, dominates the decrease of pore specific surface area and pore volume in this evolution stage. Besides, the pore development of the samples is not only affected by temperature, but also by the sedimentary evolution time, mainly for pores over $10 \mathrm{~nm}$.

\section{Increase stage of pore specific surface area and pore volume}

During the increase of pore specific surface area and pore volume (Figs. 4, 5), the overall trend for pores with the diameter below $10 \mathrm{~nm}$ and between 10 and $100 \mathrm{~nm}$ increases with the simulation temperature. For pores greater than $100 \mathrm{~nm}$, there is no obvious rule to follow in its evolution trend. In general, the changes of pores whose diameters are below $100 \mathrm{~nm}$ dominate the increase of pore volume in this stage. Combined with the decrease process, it can be seen that within the experiment temperature range of this study, shale pores with the diameter between 10 and $100 \mathrm{~nm}$ always increase with the rise of pyrolysis temperature. In other words, it is mainly pores below $10 \mathrm{~nm}$, especially micropores below $2 \mathrm{~nm}$ that cause the changes of pore specific surface area and pore volume in Fig. 1c and Fig. 1: first decrease and then increase with the experiment temperature.

\section{Hydrocarbon generation rate and pore structure}

From the relationship between hydrocarbon generation rate and pore structure change, it can be seen that there are significant differences in specific surface area and pore volume changes at different heating rates under similar hydrocarbon generation rate. The specific surface area and pore volume at $2{ }^{\circ} \mathrm{C} / \mathrm{h}$ are obviously larger than those at $20^{\circ} \mathrm{C} / \mathrm{h}$ during
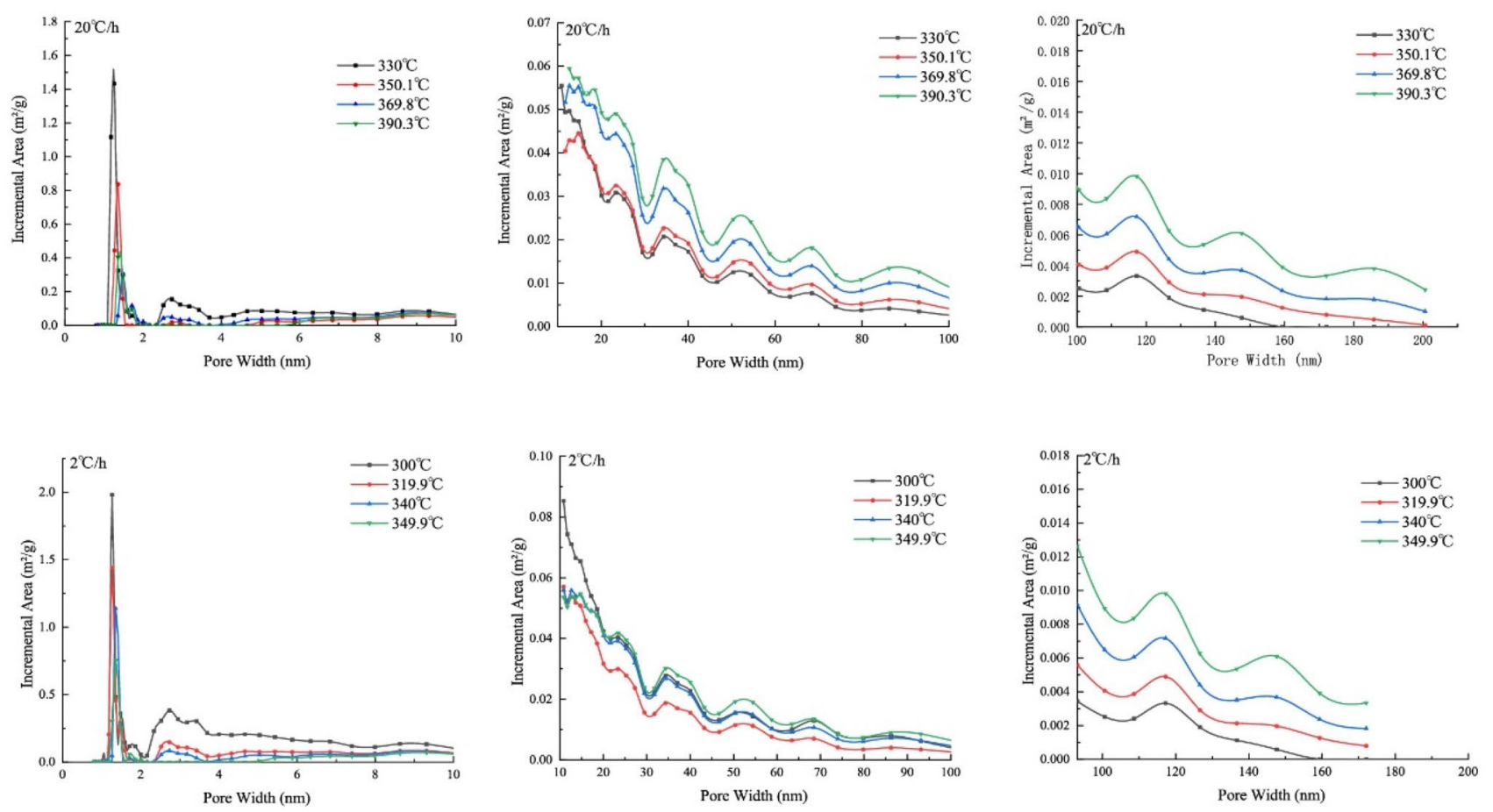

Fig. 2 Variation of pore structure in the phase of decreasing pore surface area 
the decrease stage of specific surface area and pore volume. However, during the increase of specific surface area, there is little difference for those at the two heating rates. It indicates that pore evolution time may be an important factor affecting pore development at this stage. According to the difference between Figs. 2 and 3 pores with a diameter above $10 \mathrm{~nm}$ may be the direct cause of this difference. Under similar hydrocarbon generation quantity, the development of corresponding organic pores should be similar from the perspective of organic matter transformation. After comparing the pore structure parameters and hydrocarbon generation quantity at two heating rates in Fig. 6, it is found that when the hydrocarbon generation quantity is similar, the pore structure parameters are quite different. It can be inferred that the formation of this difference mainly comes from the change of inorganic origin pores. Previous studies believe that large volume loss occurred during the process of oil
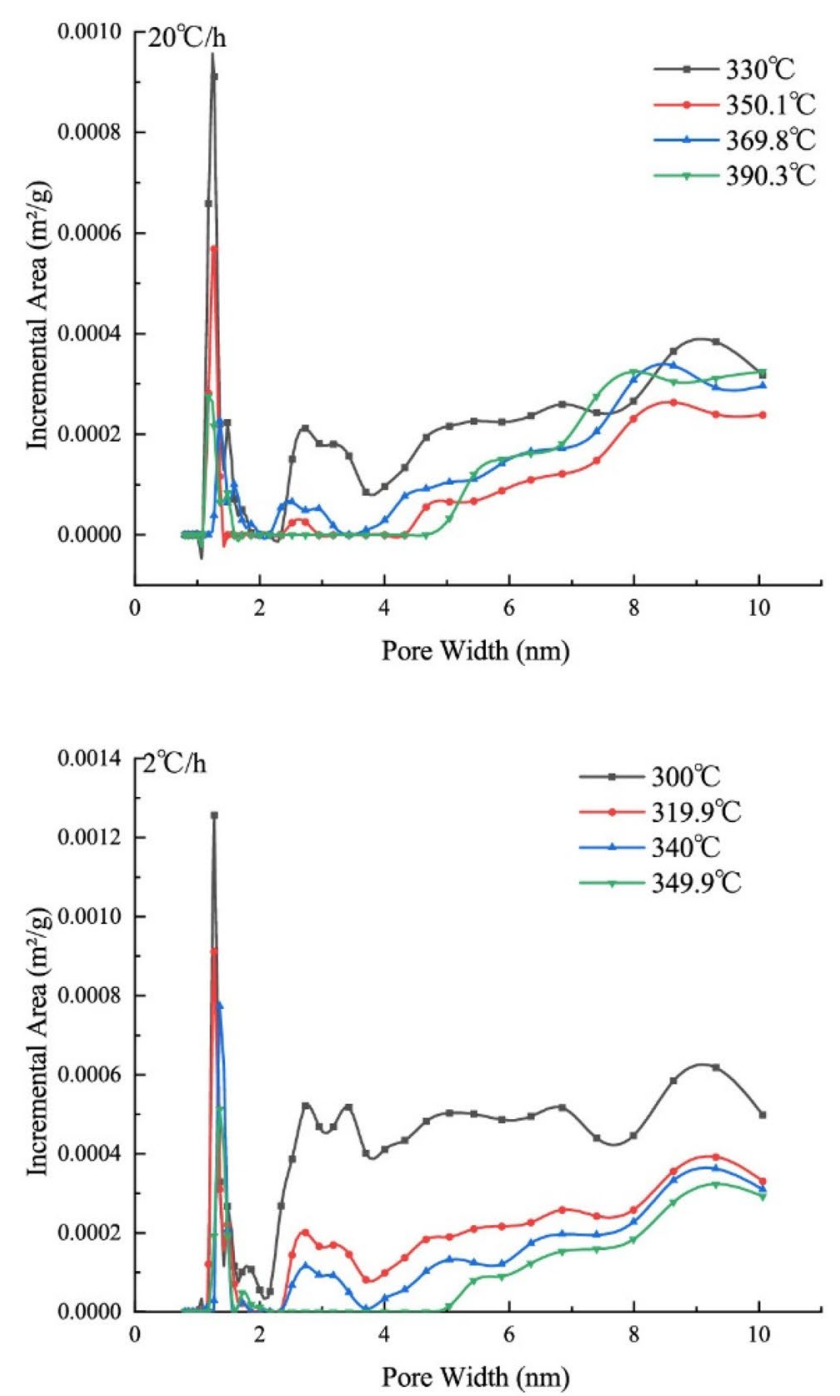

Fig. 3 Evolution of pore structure in total pore volume reduction stage generation is conducive to the forming of large pores and cracks. But the process of gas generation is conducive to the formation of small cavernous pores (Guo et al. 2020). Meanwhile, some scholars point out that the formation of cavernous organic pores is not only affected by the characteristics of organic matters, but also related to gas expansion (Song et al. 2021). With the increasing simulated temperatures, asphalt and liquid hydrocarbon tend to crack. The devolatilization process of gaseous hydrocarbons leads to the rapid formation and development of organic pores (Milliken et al. 2012), and pyrobitumen is also considered as an important carrier for the development of organic pores (Bernard et al. 2012). As a result, a large number of previous studies have proved that, the organic pores formed in the hydrocarbon generation process of organic-rich shale are mainly micropores, while the inorganic pores are mainly mesopores and macropores (Curtis et al. 2012; Fu et al. 2019; Li et al. 2016;
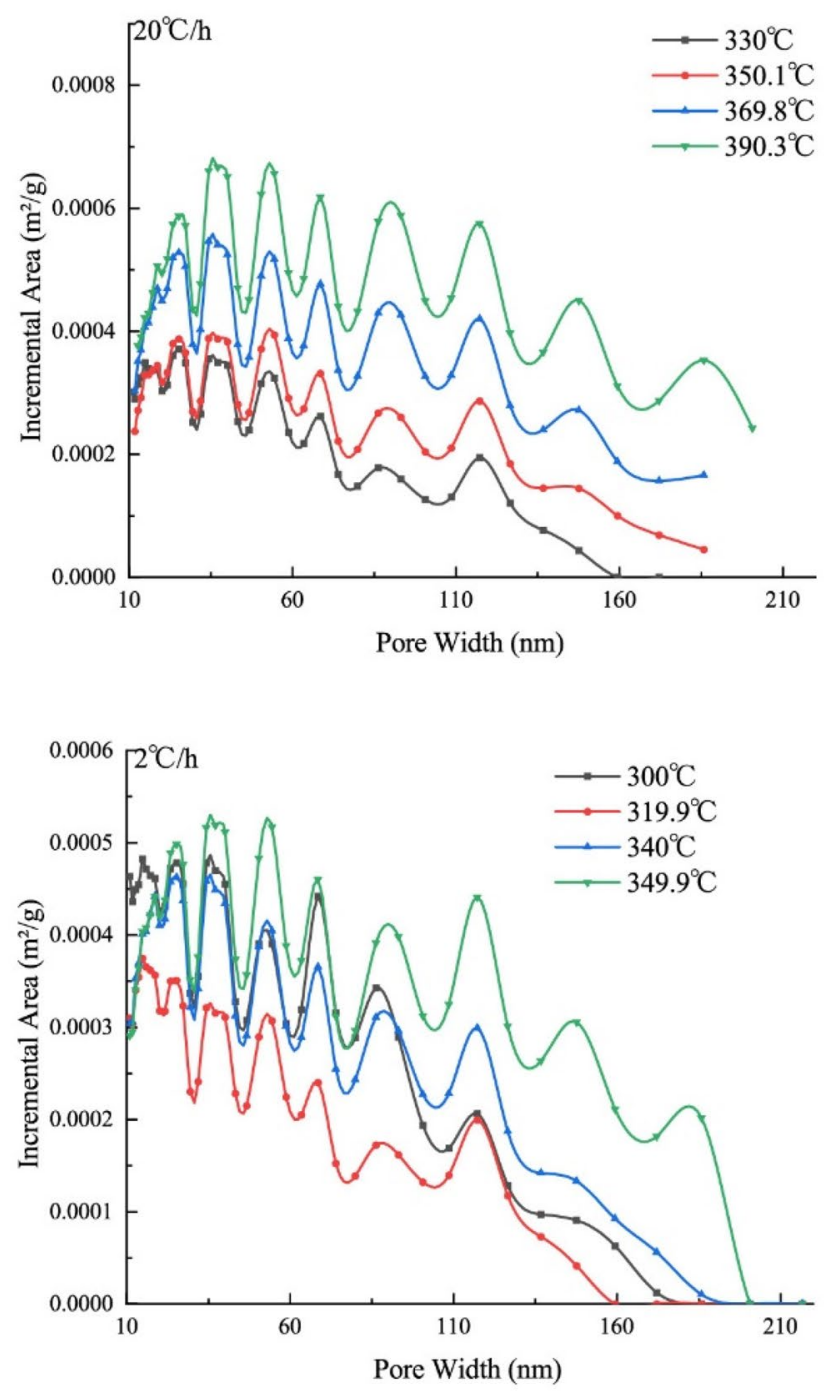
Ma et al. 2015). In addition, in this closed experimental system, with the increasing simulated temperatures, the amount of pyrobitumen formed by the cracking of corresponding liquid hydrocarbons will also increase, and resulting in the increasing carrier for the development of organic pores. This also show the increasing degree of development on the corresponding micropores (Mathia et al. 2016). Therefore, the development of organic pores first decreases and then increases with the rise of temperature, which is the core factor affecting the development and evolution of pores in the whole organic-rich shale. For inorganic origin pores, for the sealing degree of the experimental system affects the spatial location of organic matter in shale, and the organic matter filling in inorganic mineral pores has a protective effect on inorganic pores. Thus, these inorganic pores will be released with the continuous consumption of filled organic matter in the stage of higher simulated temperatures (Su et al. 2020). And in addition, the pores increase more with the increase of temperature at a slow heating rate. It be related to the dissolution of minerals by organic acids produced by pyrolysis of organic matter during the evolution of hydrocarbon generation (Cama et al., 2006). Or it may be caused by the crystal structure deformation of mineral components under the combined action of temperature and pressure Fig. 7.

\section{Pore structure evolution characteristics and geological significance}

When Easy\% Ro is below $0.82 \%$, the pore specific surface area and pore volume decrease with the increase of thermal evolution degree. When Easy\%Ro ranges from 0.8 to $1.4 \%$, they increase with the thermal evolution degree. Obviously, there are two possible reasons for the decrease of pore size in the lower evolution stage of organic matters. First, there are fewer primary pores in the original samples, and the pyrolysis productions generated after artificial pyrolysis are stored in these undamaged primary pores. Second, organic matters exist in these primary pores, and the pore space generated by the organic matter consumed by pyrolysis is refilled by the newly generated pyrolysis products, and there is a possibility of insufficient filling (Sun et al. 2015, 2019; Kuila et al. 2014; Bai et al. 2012). In addition, the difference between the two evolution stages at different heating rates is obvious in specific surface area. A main difference is that the pore specific surface area under the evolution condition with a slower heating rate is slightly higher than that with a more rapid heating rate. It means that rapid settlement may be inconducive to the development of nano-pores under geological conditions. Another difference is that, compared with the specific surface area of pores, the difference of pore
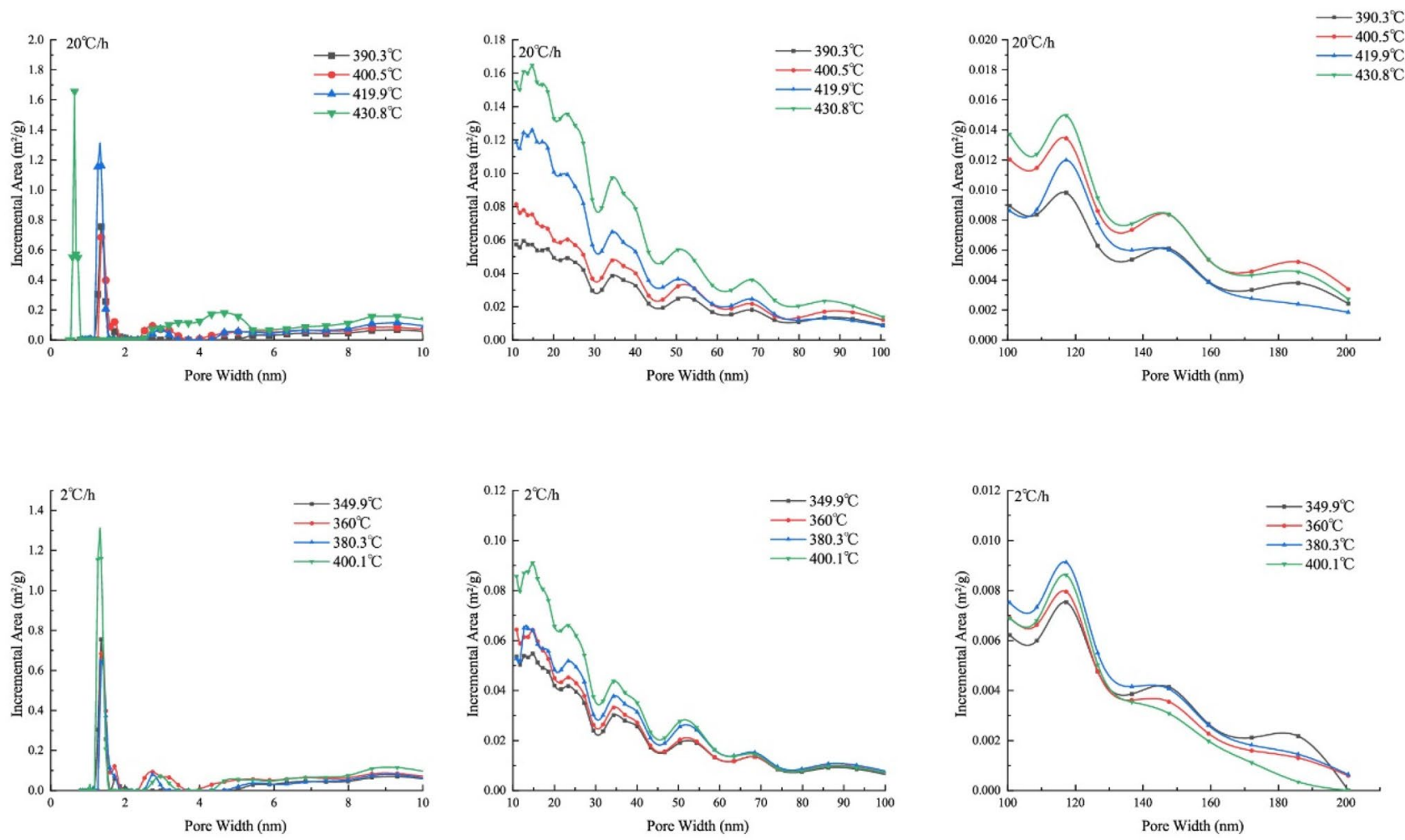

Fig. 4 Variation of pore structure in the stage of increase of total pore surface area 

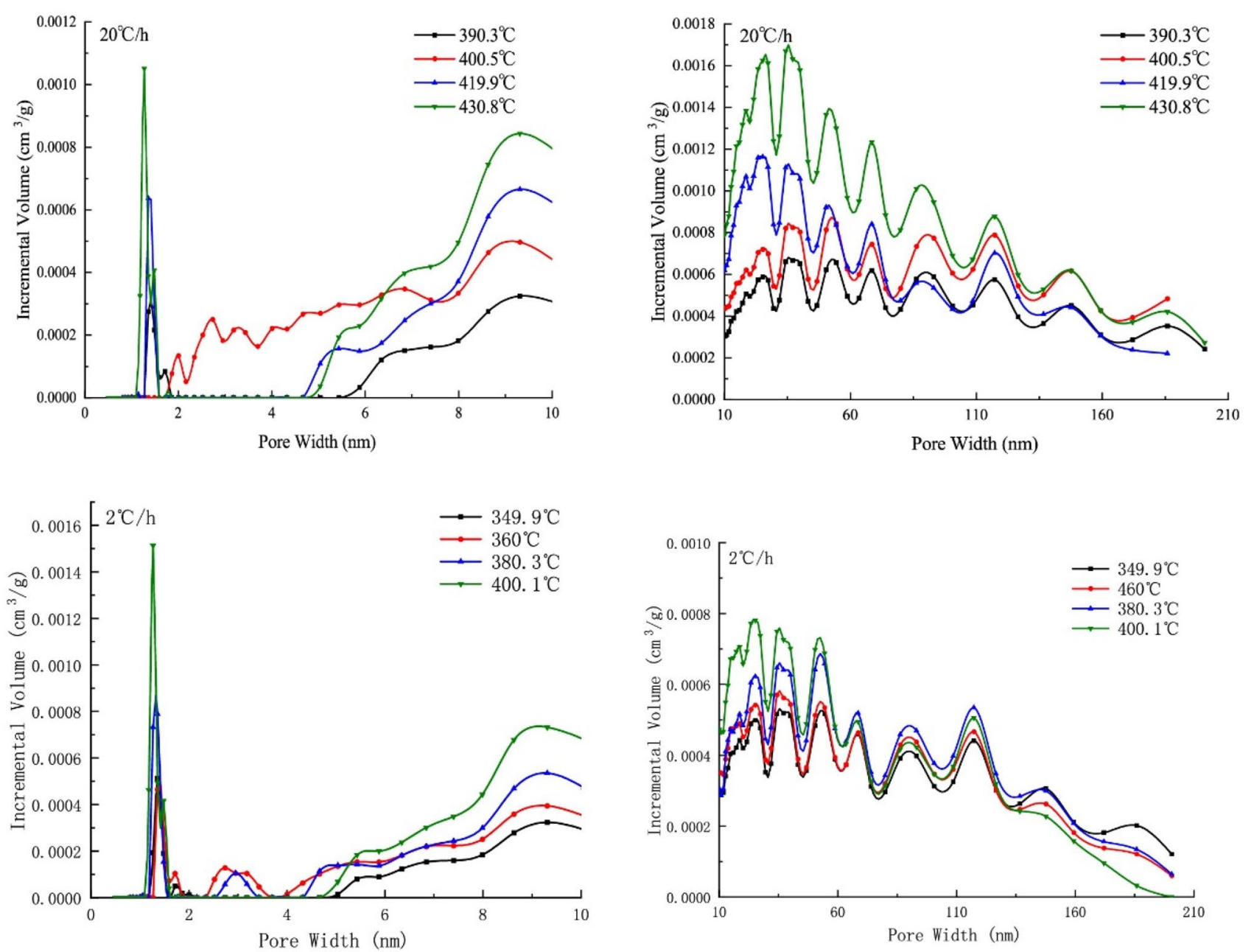

Fig. 5 Variation of pore structure in the stage of total pore volume increase

volume at different heating rates is relatively limited. It indicates that the main factor causing this difference is micropores dominated by organic pores, rather than mesopores and macropores dominated by inorganic pores. Therefore, clarifying the proportion of organic pores under different heating rates will play an important role in the study of oil and gas storage space.

\section{Conclusion}

The hydrocarbon generation process of continental shale organic matter is closely related to the evolution of pore structure characteristics. Based on the thermal simulation experiment combined with low temperature physical adsorption experiment under the gold pipe closed system, we obtain the following conclusions:

(1) During the simulation experiment of hydrocarbon generation in continental shale, the specific surface area and pore volume of nano-pores with the diameter below $10 \mathrm{~nm}$ first decrease and then increase with the rise of simulation temperature, while those of pores with the diameter above $10 \mathrm{~nm}$ increase all the way. The evolution trend of total specific surface area and pore volume is controlled by pores below $10 \mathrm{~nm}$, especially micropores below $2 \mathrm{~nm}$.

(2) Judging from the relationship between hydrocarbon generation quantity and pore structure parameters at different heating rates, the development of organic pores first decreases and then increases with the rise of temperature, which is the key factor affecting the whole development and evolution trend of pores in the organic-rich shale. On the one hand, the inorganic origin pores are related to the dissolution of minerals by organic acids produced by pyrolysis of organic matter during the evolution of hydrocarbon generation. On the other hand, they may be affected by the crystal structure deformation of mineral components under the combined action of temperature and pressure. 

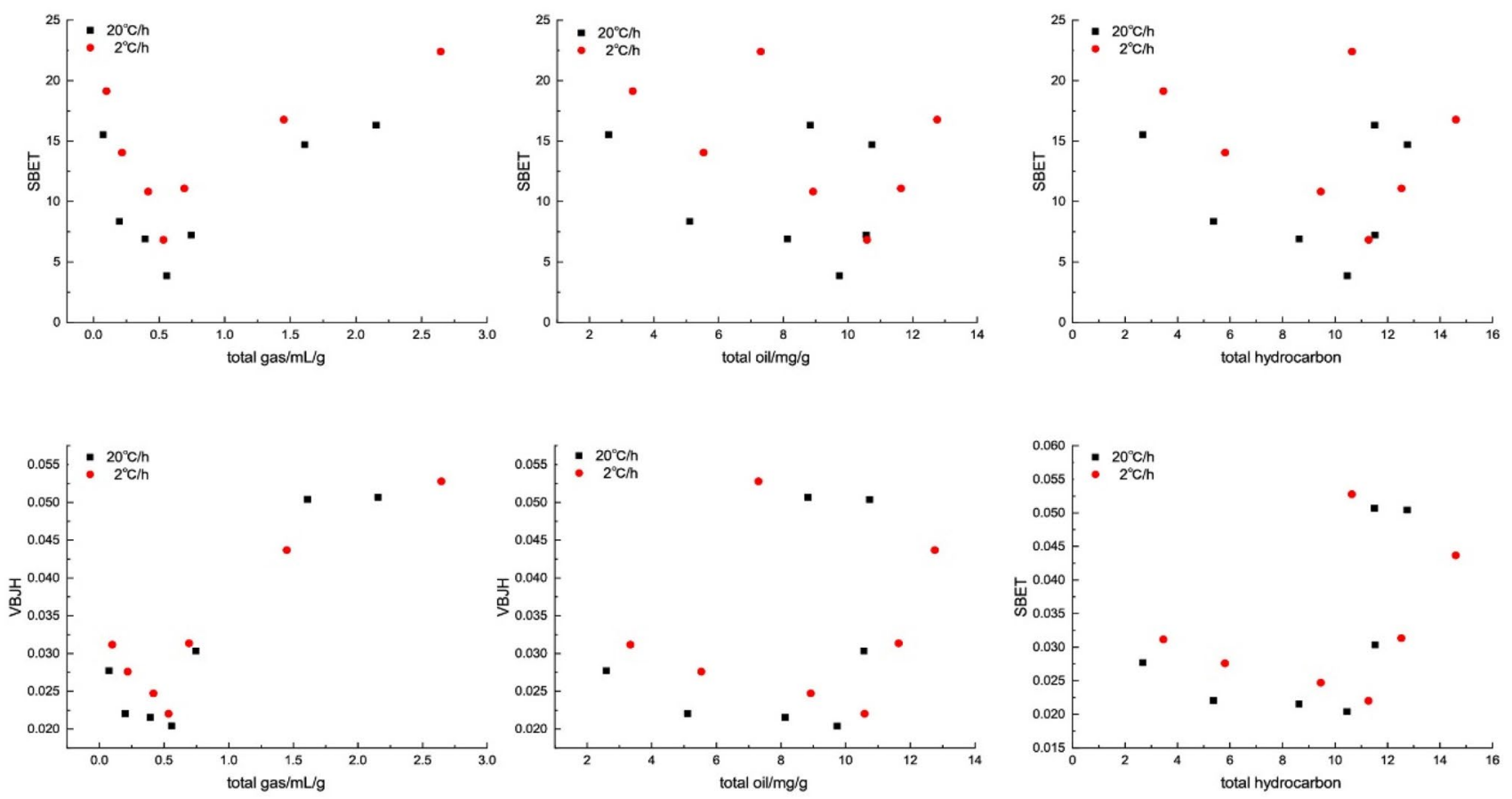

Fig. 6 Relationship between hydrocarbon generation rate and pore structure characteristics
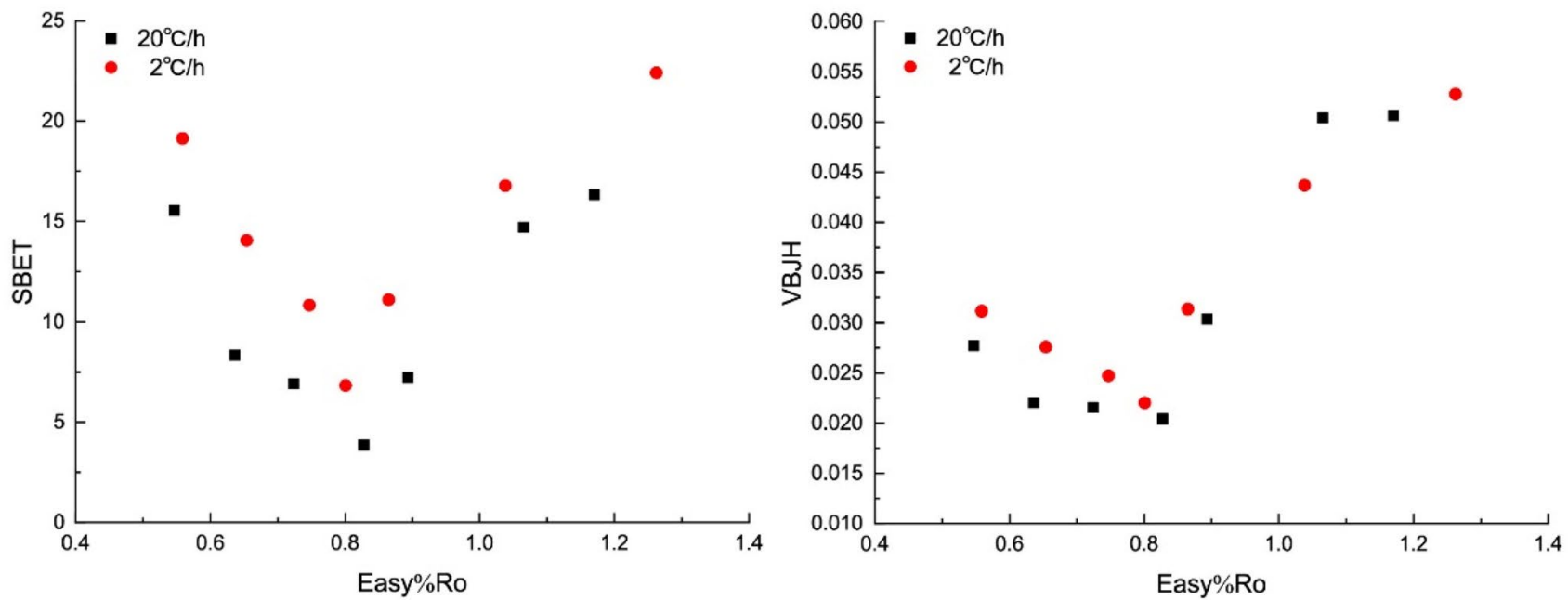

Fig. 7 Thermal evolution and pore structure characteristics

(3) The experimental results demonstrate that rapid settlement under geological conditions is inconducive to the development of nanopores, especially micropores dominated by organic pores.

Acknowledgements This research was supported by the Natural Science Foundation Project of Inner Mongolia (No.2018LH04001), Hondlon District science and technology projects (No.YF2020015), National Natural Science Foundation of China (Grant Nos.:41903060), Natural Science Fund Youth Fund project of Shaanxi Province
(No.2021JQ-953) and Postdoctoral Fund Enterprise Project of Shaanxi province (No.2018BSHQYXMZZ07).

\section{Declarations}

Conflict of interest The authors declare that they have no known competing financial interests or personal relationships that could have appeared to influence the work reported in this paper. 
Open Access This article is licensed under a Creative Commons Attribution 4.0 International License, which permits use, sharing, adaptation, distribution and reproduction in any medium or format, as long as you give appropriate credit to the original author(s) and the source, provide a link to the Creative Commons licence, and indicate if changes were made. The images or other third party material in this article are included in the article's Creative Commons licence, unless indicated otherwise in a credit line to the material. If material is not included in the article's Creative Commons licence and your intended use is not permitted by statutory regulation or exceeds the permitted use, you will need to obtain permission directly from the copyright holder. To view a copy of this licence, visit http://creativecommons.org/licenses/by/4.0/.

\section{References}

Bai JR, Wang Q, Jiao GJ (2012) Study on the pore structure of oil shale during low-temperature pyrolysis. Enrgy Proced 17:1689-1696. https://doi.org/10.1016/j.egypro.2012.02.299

Bernard S, Horsfield B, Schulz HM, Wirth R, Schreiber A, Sherwood N (2012) Geochemical evolution of organic-rich shales with increasing maturity: a stxm and tem study of the posidonia shale (lower toarcian, northern germany). Mar Pet Geol 31(1):70-89

Cama J, Ganor J (2006) The effects of organic acids on the dissolution of silicate minerals: a case study of oxalate catalysis of kaolinite dissolution. Geochim Cosmochim Acta 70(9):2191-2209. https://doi.org/10.1016/j.gca.2006.01.028

Curtis JB (2002) Fractured shale-gas systems. AAPG Bull 86(11):1921-1938

Curtis ME, Cardott BJ, Sondergeld CH, Rai CS (2012) Development of organic porosity in the Woodford Shale with increasing thermal maturity. Int J Coal Geol 103:26-31. https://doi.org/10. 1016/j.coal.2012.08.004

Fu DL, Xu GS, Tian T, Qin JQ, Yang F (2019) Composition of the Shales in Niutitang formation at Huijunba Syncline and its influence on microscopic pore structure and gas adsorption. Petrophysics 60(3):373-383. https://doi.org/10.30632/PJV60 N3-2019a1

Fu DL, Xu GS, Ma L, Yang F, He D, Duan Z, Ma Y (2020) Gas generation from coal: taking Jurassic coal in the Minhe Basin as an example. Int J Coal Sci Technol 7(3):611-622

Guo HJ, Jia WL, He RL, Yu CL, Song JZ, Peng PA (2020) Distinct evolution trends of nanometer-scale pores displayed by the pyrolysis of organic matter-rich lacustrine shales: implications for the pore development mechanisms. Mar Petrol Geol. https://doi.org/ 10.1016/j.marpetgeo.2020.104622

Huang H, Sun W, Ji W, Zhang R, Du K, Zhang S, Ren D, Wang Y, Chen L, Zhang X (2018) Effects of pore-throat structure on gas permeability in the tight sandstone reservoirs of the Upper Triassic Yanchang formation in the Western Ordos Basin, China. J Petro Sci Eng 162:602-616

Jarvie DM, Hill RJ, Ruble TE, Pollastro RM (2007) Unconventional shale-gas systems: the Mississippian Barnett shale of north-central Texas as one model for thermogenic shale-gas assessment. AAPG Bull 91(4):475-499

Jiang Z, Zhang DX, Zhao JL, Zhou YQ (2017) Experimental investigation of the pore structure of triassic terrestrial shale in the Yanchang Formation, Ordos Basin, China. J Nat Gas Sci Eng 46:436-450. https://doi.org/10.1016/j.jngse.2017.08.002

Jiang ZX, Li TW, Gong HJ, Jiang T, Chang JQ, Ning CX, Su SY, Chen WT (2020) Characteristics of low-mature shale reservoirs in Zhanhua Sag and their influence on the mobility of shale oil. Ac Petro Sinica 41(12):1587-1600 ((in Chinese))
Kuila U, Mccarty DK, De Rkowski A, Fischer TB, Prasad M (2014) Total porosity measurement in gas shales by the water immersion porosimetry (wip) method. Fuel 117:1115-1129

Li JJ, Shi YL, Zhang XW, Chen X, Yan YX, Zhu JX, Lu SF, Wang M (2014) Control factors of enrichment and producibility of shale oil: a case study of Biyang Depression. Earth Sci- J China U Geosci 39(7):848-857 ((in Chinese))

Li J, Zhou SX, Li YJ, Ma Y, Yang YA, Li CC (2016) Effect of organic matter on pore structure of mature lacustrine organic-rich shale: a case study of the Triassic Yanchang shale, Ordos Basin, China. Fuel 185:421-431. https://doi.org/10.1016/j.fuel.2016.07.100

Li P, Jia CZ, Jin ZJ, Liu QY, Zheng M, Huang ZK (2019) The characteristics of movable fluid in the Triassic lacustrine tight oil reservoir: a case study of the Chang 7 member of Xin'anbian Block, Ordos Basin, China. Mar Petrol Geol 102:126-137. https://doi. org/10.1016/j.marpetgeo.2018.11.019

Loucks RG, Reed RM, Ruppel SC, Jarvie DM (2009) Morphology, genesis, and distribution of nanometer-scale pores in siliceous mudstones of the mississippian barnett shale. J Sediment Res 79(11-12):848-861. https://doi.org/10.2110/jsr.2009.092

Ma Y, Zhong NN, Li DH, Pan ZJ, Cheng LJ, Liu KY (2015) Organic matter/clay mineral intergranular pores in the Lower Cambrian Lujiaping Shale in the north-eastern part of the upper Yangtze area, China: a possible microscopic mechanism for gas preservation. Int J Coal Geol 137:38-54. https://doi.org/10.1016/j.coal. 2014.11.001

Mathia EJ, Bowen L, Thomas KM, Aplin AC (2016) Evolution of porosity and pore types in organic-rich, calcareous, Lower Toarcian Posidonia Shale. Mar Petrol Geol 75:117-139. https://doi. org/10.1016/j.marpetgeo.2016.04.009

Milliken KL, Esch WL, Reed RM, Zhang TW (2012) Grain assemblages and strong diagenetic overprinting in siliceous mudrocks, Barnett Shale (Mississippian), Fort Worth Basin. Texas AAPG Bull 96(8):1553-1578. https://doi.org/10.1306/12011111129

Montgomery SL, Jarvie DM, Bowker KA, Pollastro RM (2005) Mississippian barnett shale, fort worth basin, north-central texas: gasshale play with multi-trillion cubic foot potential. AAPG Bull 89(2):155-175. https://doi.org/10.1306/09170404042

Ning CX, Ma ZL, Jiang ZX, Su SY, Li TW, Zheng LJ, Wang GZ, Li FX (2020) Effect of shale reservoir characteristics on shale oil movability in the lower third member of the Shahejie formation. Zhanhua Sag Acta Geol Sin-Engl 94(2):352-363. https://doi.org/ 10.1111/1755-6724.14284

Ross DJK, Bustin RM (2009) The importance of shale composition and pore structure upon gas storage potential of shale gas reservoirs. Mar Petrol Geol 26(6):916-927. https://doi.org/10.1016/j.marpe tgeo.2008.06.004

Song DJ, Wang XQ, Tuo JC, Wu CJ, Zhang MF, Su L, He W (2021) A comprehensive study on the impacts of rock fabric on hydrocarbon generation and pore structure evolution of shale under semi-confined condition. Mar Petrol Geol. https://doi.org/10. 1016/j.marpetgeo.2020.104830

Su KM, Lu JG, Zhang HX, Chen SJ, Li Y, Xiao ZL, Qiu W, Han MM (2020) Quantitative study on hydrocarbon expulsion mechanism based on micro-fracture. Geosci Front 11(6):1901-1913. https:// doi.org/10.1016/j.gsf.2020.05.013

Sun LN, Tuo JC, Zhang MF, Wu CJ, Wang ZX, Zheng YW (2015) Formation and development of the pore structure in Chang 7 member oil-shale from Ordos Basin during organic matter evolution induced by hydrous pyrolysis. Fuel 158:549-557. https:// doi.org/10.1016/j.fuel.2015.05.061

Sun LN, Tuo JC, Zhang MF, Wu CJ, Chai SQ (2019) Pore structures and fractal characteristics of nano-pores in shale of Lucaogou formation from Junggar Basin during water pressure-controlled artificial pyrolysis. J Anal Appl Pyrol 140:404-412. https://doi. org/10.1016/j.jaap.2019.04.020 
Tian H, Xiao XM, Wilkins RWT, Tang YC (2008) New insights into the volume and pressure changes during the thermal cracking of oil to gas in reservoirs: Implications for the in-situ accumulation of gas cracked from oils. AAPG Bull 92(2):181-200. https://doi. org/10.1306/09210706140

Tian H, Pan L, Xiao XM, Wilkins RWT, Meng ZP, Huang BJ (2013) A preliminary study on the pore characterization of lower Silurian black shales in the Chuandong Thrust Fold Belt, southwestern China using low pressure N2 adsorption and FE-SEM methods. Mar Pet Geol 48:8-19

Topor T, Derkowski A, Ziemianski P, Szczurowski J, McCarty DK (2017) The effect of organic matter maturation and porosity evolution on methane storage potential in the Baltic Basin (Poland) shale-gas reservoir. Int J Coal Geol 180:46-56. https://doi.org/10. 1016/j.coal.2017.07.005

Wang QT, Lu H, Greenwood P, Shen CC, Liu JZ, Peng PA (2013) Gas evolution during kerogen pyrolysis of Estonian Kukersite shale in confined gold tube system. Org Geochem 65:74-82. https://doi. org/10.1016/j.orggeochem.2013.10.006

Wang PF, Jiang ZX, Yin LS, Chen L, Li Z, Zhang C, Li TW, Huang P (2017) Lithofacies classification and its effect on pore structure of the Cambrian marine shale in the Upper Yangtze Platform, South China: Evidence from FE-SEM and gas adsorption analysis. J
Petrol Sci Eng 156:307-321. https://doi.org/10.1016/j.petrol.2017. 06.011

Wu ST, Zhu RK, Cui JG, Bai CJW, B, Zhang XX, Jin X, Zhu DS, You JC, LI X, (2015) Characteristics of lacustrine shale orosity evolution, Triassic Chang 7 Member, Ordos Basin. NW China Petrol Explor Dev 42(2):167-176 ((in Chinese))

Wu CJ, Tuo JC, Zhang LF, Zhang MF, Li J, Liu Y, Qian Y (2017) Pore characteristics differences between clay-rich and clay-poor shales of the Lower Cambrian Niutitang Formation in the Northern Guizhou area, and insights into shale gas storage mechanisms. Int J Coal Geol 178:13-25. https://doi.org/10.1016/j.coal.2017. 04.009

Zhao WZ, Hu SY, Hou LH, Yang T, Li X, Guo BC, Yang Z (2020) Types and resource potential of continental shale oil in China and its boundary with tight oil. Petrol Explor Dev+ 47(1):1-11. https://doi.org/10.1016/S1876-3804(20)60001-5

Publisher's Note Springer Nature remains neutral with regard to jurisdictional claims in published maps and institutional affiliations. 